\title{
Deep Arctic Ocean warming during the last glacial cycle
}

\author{
T. M. Cronin ${ }^{1 \star}$, G. S. Dwyer ${ }^{2}$, J. Farmer ${ }^{1,3}$, H. A. Bauch ${ }^{4}$, R. F. Spielhagen ${ }^{4}$, M. Jakobsson ${ }^{5}$, J. Nilsson ${ }^{6}$, \\ W. M. Briggs $\mathrm{Jr}^{7 \dagger}$ and A. Stepanova ${ }^{8}$
}

In the Arctic Ocean, the cold and relatively fresh water beneath the sea ice is separated from the underlying warmer and saltier Atlantic Layer by a halocline. Ongoing sea ice loss and warming in the Arctic Ocean ${ }^{1-7}$ have demonstrated the instability of the halocline, with implications for further sea ice loss. The stability of the halocline through past climate variations ${ }^{8-10}$ is unclear. Here we estimate intermediate water temperatures over the past 50,000 years from the $\mathrm{Mg} / \mathrm{Ca}$ and $\mathrm{Sr} / \mathrm{Ca}$ values of ostracods from 31 Arctic sediment cores. From about 50 to 11 kyr ago, the central Arctic Basin from 1,000 to 2,500 m was occupied by a water mass we call Glacial Arctic Intermediate Water. This water mass was 1-2 ${ }^{\circ} \mathrm{C}$ warmer than modern Arctic Intermediate Water, with temperatures peaking during or just before millennial-scale Heinrich cold events and the Younger Dryas cold interval. We use numerical modelling to show that the intermediate depth warming could result from the expected decrease in the flux of fresh water to the Arctic Ocean during glacial conditions, which would cause the halocline to deepen and push the warm Atlantic Layer into intermediate depths. Although not modelled, the reduced formation of cold, deep waters due to the exposure of the Arctic continental shelf could also contribute to the intermediate depth warming.

Our study of deep Arctic Ocean temperature variability during the last glacial-interglacial cycle focuses on sediment cores from Arctic submarine ridges (Lomonosov, Gakkel and Mendeleev), Nansen and Makarov abyssal plains, Yermak Plateau and Morris Jesup Rise, Laptev Sea Slope, Chukchi Shelf and the Iceland Plateau in the central Nordic seas (Greenland, Norwegian and Iceland seas; Fig. 1a and Supplementary Information). Modern Arctic water masses in these regions (Fig. 1b) consist of cold, low-salinity water from the Polar Mixed Layer that is separated from the underlying warm Atlantic Layer by a strong halocline. Atlantic water enters the Arctic Basin in two branches, one through the Fram Strait and the other through the Barents Sea ${ }^{11,12}$. The inflowing Atlantic water is entrained with water formed along the margins to form Arctic Intermediate Water (AIW), which lies above Eurasian and Amerasian Basin Deep Water (Fig. 1b). The results presented here show that the central Arctic Basin at depths occupied by today's AIW and upper Eurasian Basin Deep Water and Amerasian Basin Deep Water experienced temperature variability during the last glacial period and, to a lesser degree, the Holocene interglacial, signifying large changes in circulation in Arctic and subarctic seas and variability in halocline depth.
To reconstruct Arctic bottom water temperature (BWT), we used $\mathrm{Mg} / \mathrm{Ca}$ palaeothermometry of the deep-sea ostracod (Crustacea) Krithe glacialis $^{13}$ from cores between $\sim 250$ and 3,500 m water depth (Supplementary Fig. S3 and Methods). Both field and laboratory studies show a temperature dependence of $\mathrm{Mg} / \mathrm{Ca}$ ratios in marine ostracods, which secrete their shells from ambient water during the moulting process. The Arctic is supersaturated with respect to calcite $(\Omega>1.25)$ at our core depths and there is no evidence for post-mortem shell dissolution. Moreover, unlike some deep-sea benthic foraminifers, ostracod $\mathrm{Mg} / \mathrm{Ca}$ ratios are not influenced by a carbonate ion effect in the Arctic and North Atlantic oceans ${ }^{14}$. In addition to the observed $\mathrm{Mg} / \mathrm{Ca}$-temperature relationship, the within-shell inverse relationship between $\mathrm{Mg} / \mathrm{Ca}_{\mathrm{Kg}}$ and $\mathrm{Sr} / \mathrm{Ca}$ Kg found throughout the Arctic-Nordic seas (Supplementary Fig. S3, $r^{2}=0.5$ ) has also been recognized in shells cultured in laboratory experiments ${ }^{15}$, supporting a temperature control on metal ratios.

The contrast between mean $\mathrm{Mg} / \mathrm{Ca}$-based temperature for Holocene (11.7-0 kyr вр), Marine oxygen isotope stage 3 (MIS3) Glacial Arctic Intermediate Water (GAIW; 25-50 kyr вр) and the modern central Arctic is shown in Fig. 2. The highest BWTs $\left(\sim 2-4{ }^{\circ} \mathrm{C}, \mathrm{Mg} / \mathrm{Ca}_{\mathrm{Kg}}\right.$ values $\sim 13-20 \mathrm{mmol} \mathrm{mol}^{-1}$ ) come from MIS3 samples (blue curve, Fig. 2) concentrated at depths 1,000-2,400 m and are $1-3 \pm 1.0^{\circ} \mathrm{C}$ warmer $\left(\mathrm{Mg} / \mathrm{Ca}_{\mathrm{Kg}}\right.$ values $1-6 \mathrm{mmol} \mathrm{mol}^{-1}$ higher) than both Holocene temperatures from the same or nearby core sites (red curve, Fig. 2) and modern central Arctic conductivity-temperature-depth temperatures (black curve). In contrast, BWT values from Arctic sites below 3,000 m water depth show no discernible difference between MIS3 and Holocene values. MIS3 $\mathrm{Mg} / \mathrm{Ca}_{\mathrm{Km}}$ (K. minima) values are available from fewer intermediate depth sites, but the pattern is nonetheless similar to that for K. glacialis (Supplementary Fig. S4).

To examine temporal variability in BWT in more detail, composite records of $\mathrm{Mg} / \mathrm{Ca} \mathrm{Kg}_{\mathrm{Kg}} \mathrm{Mg} / \mathrm{Ca}_{\mathrm{Krithe}}$ (both species) and $\mathrm{Sr} / \mathrm{Ca}_{\mathrm{Krithe}}$ were constructed from 28 cores located within a relatively small region of the central Arctic Ocean (Fig. 3). $\mathrm{Mg} / \mathrm{Ca}$ records for individual cores show the same general patterns as the composite record, although there is regional variability in the amplitude of the $\mathrm{Mg} / \mathrm{Ca}$ oscillations (Supplementary Fig. S5). Also plotted in Fig. 3 is the $\mathrm{Mg} / \mathrm{Ca}$ curve from the Iceland Plateau core PS1243 located at 2,710 m water depth. It should be noted that minimal sediment was deposited in the central Arctic during the Last Glacial Maximum (LGM) owing to extensive

\footnotetext{
1926A US Geological Survey Reston, Virginia 20192, USA, ${ }^{2}$ Division of Earth and Ocean Sciences, Nicholas School of the Environment, Duke University, Durham, North Carolina 27708, USA, ${ }^{3}$ Lamont-Doherty Earth Observatory of Columbia University, Palisades, New York 10964, USA, ${ }^{4}$ Mainz Academy of Sciences, Humanities and Literature and GEOMAR Helmholtz Center for Ocean Research, 24148 Kiel, Germany, ${ }^{5}$ Department of Geological Sciences, Stockholm University, 10691 Stockholm, Sweden, ${ }^{6}$ Department of Meteorology, Stockholm University, 10691 Stockholm, Sweden, ${ }^{7}$ Institute of Arctic and Alpine Research, University of Colorado, Boulder, Colorado 80309, USA, ${ }^{8}$ Paleontological Institute of Russian Academy of Sciences, Profsoyuznaya ul., 123 , Moscow, 117997, Russia. †Present address: 3000 Colorado Avenue A201, Boulder, Colorado 80303, USA. *e-mail: tcronin@usgs.gov.
} 


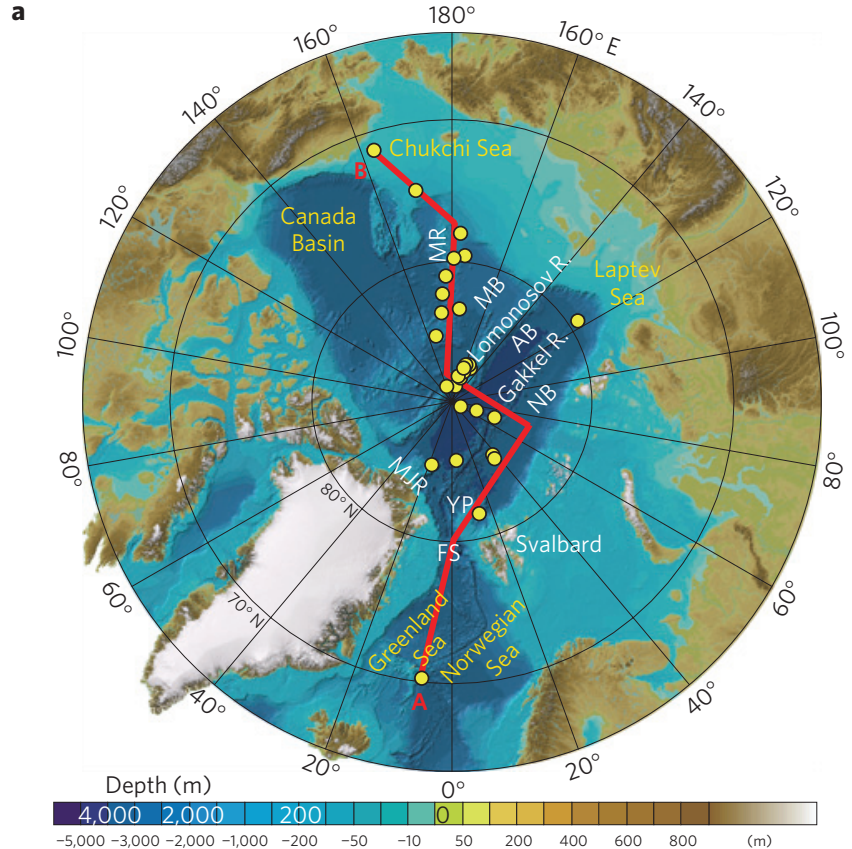

b

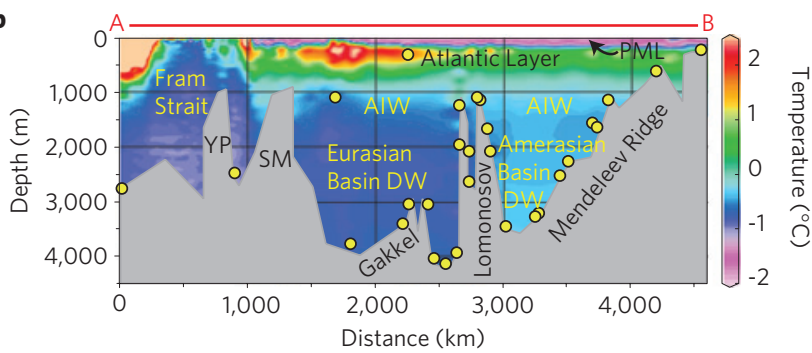

Figure 1 | Core site location map. a, Map showing the location of the sediment cores used in the palaeoceanographic reconstruction. $A B$, Amundsen Basin; FS, Fram Strait; MB, Makarov Basin; MR, Mendeleev Ridge; MJR, Morris Jesup Rise; YP, Yermak Plateau. The base map is from IBCAO (http://www.ngdc.noaa.gov/mgg/bathymetry/arctic/).

b. Arctic-Nordic seas temperature section A to B in a from Ocean Data View (http://odv.awi.de/). PML, Polar Mixed Layer; DW, Deep Water; AIW, Arctic Intermediate Water. The bathymetry is approximate.

ice cover $^{16}$ in contrast to the continuous sedimentation at site PS1243. The North Greenland Ice Core Project (NGRIP) ice core $\delta^{18} \mathrm{O}$ record is also shown to allow comparison with millennial climate variability associated with Dansgaard-Oeschger (DO2-13) and Heinrich (H1-5) events.

The central Arctic $\mathrm{Mg} / \mathrm{Ca}$ Kg and $\mathrm{Mg} / \mathrm{Ca}_{\text {Krithe }}$ curves show a pattern of oscillating $\mathrm{Mg} / \mathrm{Ca}$ values during $\mathrm{MIS}$, higher values around the LGM-H1 interval (23-18 kyr вP), sharply decreasing values during the last deglaciation and lower but still variable values during the Holocene. The $\mathrm{Sr} / \mathrm{Ca}_{\mathrm{Krithe}}$ curve follows a similar pattern but generally opposite in sign. The Iceland Plateau core PS1243 $\mathrm{Mg} / \mathrm{Ca}_{\text {Krithe }}$ curve shows a first-order pattern similar to that from the central Arctic with higher MIS3 and LGM and lower Holocene values, suggesting a common water mass history for the Nordic seas and Arctic Ocean.

Positive $\mathrm{Mg} / \mathrm{Ca}_{\text {Krithe }}$ excursions in the central Arctic centred on $\sim 47,39,30,24$ and $18 \mathrm{kyr}$ в indicate that the temperature in GAIW oscillated from $<0$ to as high as $3^{\circ} \mathrm{C}$ during this period. Although low Arctic sedimentation rates and radiocarbon age uncertainty, especially before $40 \mathrm{kyr}$ BP, prevent precise correlation to Dansgaard-Oeschger and Heinrich events seen in the NGRIP record, the warmest BWT values are observed during $\mathrm{H} 1$ and $\mathrm{H} 2$

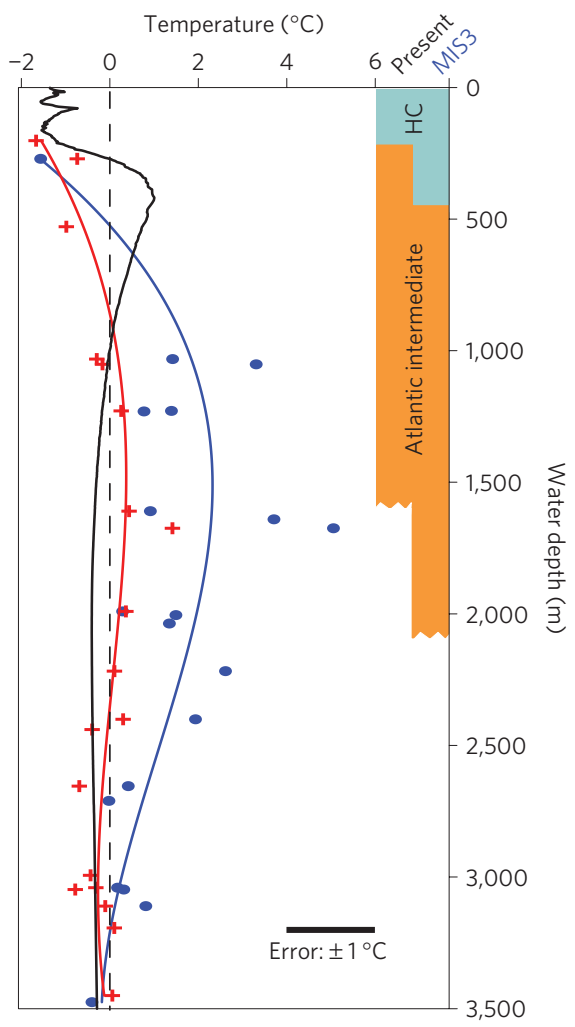

Figure 2 | Holocene and MIS3 $\mathbf{M g} /$ Ca ratios. Depth profile of late Holocene (red) and MIS3 (blue) Mg/Ca-derived $T$ ( $K$. glacialis) $(T=0.438 \times \mathrm{Mg} / \mathrm{Ca}-5.14$; Supplementary Figs S1 and S2). Red and blue lines, third-order polynomial fits. Black line, modern temperature from Amundsen Basin (ref. 29). Elevated MIS3 temperatures suggest deeper halocline $(\mathrm{HC})$ and Atlantic Intermediate Water mass at depths $1,000-2,500 \mathrm{~m}$.

( $\sim 18$ and 24 kyr вр), which are well dated in Arctic sediments. Warming during cool climate events is also indicated by the positive excursions in the $\mathrm{Mg} / \mathrm{Ca}_{\mathrm{Kg}}$ and $\mathrm{Mg} / \mathrm{Ca}_{\text {Krithe }}$ during the Younger Dryas (YD, $12.8-11.7 \mathrm{kyr} \mathrm{BP}$ ) when BWT was $0.5-2{ }^{\circ} \mathrm{C}$ warmer than those during the preceding Bølling-Allerød and succeeding early Holocene warming. Smaller warming events of $\sim 0.5-1{ }^{\circ} \mathrm{C}$ punctuated the last $11 \mathrm{kyr}$ of the Holocene interglacial, including two closely spaced excursions near the well-known $8.2 \mathrm{kyr}$ bp event, a pattern seen in high-resolution climate records ${ }^{17}$.

Intermediate depth warming events in the NorwegianGreenland seas have been proposed for glacial periods based on benthic foraminiferal isotopes, warm-water benthic species and high-productivity events ${ }^{18-20}$ from various sites. These might be attributed to release of fresh water during Heinrich events, the development of a strong halocline and extensive sea ice in the Nordic seas, and reduced outflow from the Nordic seas ${ }^{21}$. Alternative hypotheses to explain low benthic foraminiferal isotope values, and palaeoceanographic events at least for $\mathrm{H} 1$ and the YD, include freshwater inflow, sea-ice formation, weakened meridional overturning circulation $^{22}$, brine formation in the North Atlantic and Nordic seas near the Iceland-Faroes Ridge ${ }^{23}$ and hyperpycnal injection of sediment-rich fresh water in the subpolar North Atlantic $^{24}$. Using $\mathrm{Mg} / \mathrm{Ca}$ as a temperature proxy eliminates the ambiguity of oxygen and carbon isotope records and confirms the periodic presence of a warm intermediate-deep water mass throughout the central Arctic Ocean and the Nordic seas. We cannot totally rule out brine formation or hyperpycnal flows near the shelf-marginal regions of the Nordic seas-subpolar North Atlantic Ocean at times during millennial-scale climate events. 


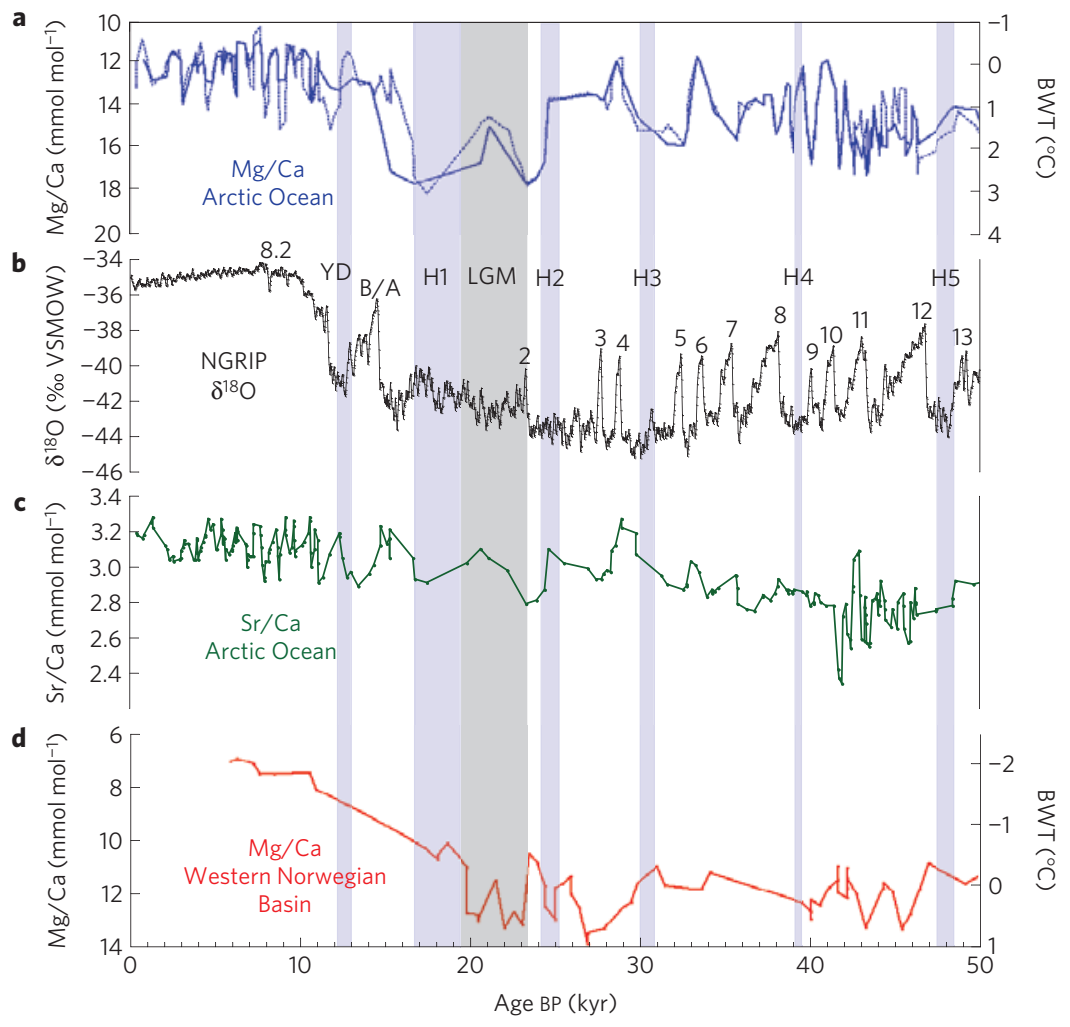

Figure 3 | Deep Arctic Ocean temperature history. a, Composite Arctic BWT (3-point smooth) from Mg/Cak.glacialis (solid line, $n=618$ specimens) and $\mathrm{Mg} / \mathrm{C} a_{\text {Krithe }}$ (corrected by $0.77, n=209$; dashed line) from 28 cores from 1,000 to 3,000 m water depth. Age models ${ }^{14} \mathrm{C}$ (Supplementary Information). b, NGRIP ice core oxygen isotopes (5-point moving average of 20-yr sampling); GICC05 age model, ref. 30. The numbers indicate Dansgaard-Oeschger events. c, Sr/Cakrithe composite Arctic curve ( $y$ axis reversed). d, Krithe Mg/Ca curve Iceland Plateau core PS1243-1/2, chronology updated from ref. 18. The vertical shaded areas are H1-5, YD and LGM.

Nonetheless, the boundary conditions in the central Arctic Ocean during MIS3 were conducive for a warm water mass to repeatedly fill the central Arctic Basin at depths of 1,000-2,500 m. These conditions included a smaller, more restricted ocean due to lower sea level by $50-120 \mathrm{~m}$, a closed Bering Strait, thick but temporally variable sea-ice cover $^{25}$ and ice shelves ${ }^{26}$, reduced convective formation of cold deep water in the Nordic seas, and minimal brine formation in the Arctic Ocean proper since $50 \mathrm{kyr}$ в (ref. 27). The upper depth limit of this warmer water mass is not yet known owing to a lack of cores from the 300 to $1,000 \mathrm{~m}$ depth interval.

One mechanism that might force the warmer Atlantic water deeper in the Arctic during MIS3 than during the Holocene involves the formation of a deeper and thicker halocline. Freshwater influx from rivers and wind-induced vertical mixing influence the depth of the modern halocline and cool the Atlantic Layer during its path along the Arctic continental slopes and ridges. However, less freshwater influx to the Arctic Ocean is expected during the reduced hydrological cycle of a stadial or glacial climate state, causing the halocline to deepen. In addition, more extensive sea-ice cover during MIS3 than during the Holocene, a lower sea level and smaller continental shelf area all serve to reduce the potential for formation of cold deep water through brines. Such a situation was proposed for MIS6 ( $\sim 140 \mathrm{kyr})$ when thick ice shelves occupied parts of the central Arctic Ocean ${ }^{26}$.

This mechanism is supported by modelling of the impact of freshwater influx on thermohaline circulation in a silled basin such as the Arctic, which suggests that circulation with a salinitydominated stratification may have two qualitatively different modes of operation $^{28}$, (see Supplementary Information). In a mixing-limited regime, such as the Holocene, the upper layer is shallower than the sill, which is the Greenland-Scotland Ridge in this case, and the flow strength decreases with increasing density difference. In contrast, in an over-mixed regime during a stadial-glacial climate, the upper layer extends below the sill and the flow strength increases with density difference. The frequent temperature oscillations shown in Fig. 3 support the idea of two distinct kinds of circulation in the Arctic Ocean. It should be emphasized that we cannot fully ascertain whether the warming of the GAIW resulted from a deepening of the halocline or from a reduced production of cold deep water as a consequence of smaller shelf area. Regardless of the mechanism, our results imply that the Arctic Ocean was extremely sensitive at least indirectly to freshwater flux in high-latitude Northern Hemisphere oceans during the last glacial and deglacial periods, and to a lesser extent, during low-amplitude climate changes of the Holocene interglacial.

\section{Methods}

Ostracod shells were brush-picked from the $>150 \mu \mathrm{m}$ dry fraction and assigned a preservation index ranging from 1 (transparent) to 7 (opaque, white; ref. 15). Shells of Arctic-Nordic species Krithe glacialis and K. minima were soaked in 5\% $\mathrm{NaOCl}$ for $16-24$ h to oxidize organic matter and remove adhering particles. Shells were triple-rinsed in deionized water, inspected under a light microscope for the remaining adhering particles and twice more rinsed with deionized water under light sonication. The shells were then dissolved in $3-30 \mathrm{ml}$ of $0.05 \mathrm{~N}$ nitric acid and the resulting aqueous solution was analysed for $\mathrm{Mg}$, $\mathrm{Sr}$ and $\mathrm{Ca}$ on a Fisons Instruments Spectraspan 7 direct current plasma atomic emission spectrometer at Duke University using ultrapure plasma-grade standard solutions. Analytical precision is approximately $2 \%$ based on replicate analysis of samples and standards. The $\mathrm{Mg} / \mathrm{Ca}$-temperature relationship for $\mathrm{K}$. glacialis is based on Arctic-Nordic seas core-top material from 50 sites $\left(50-3,500 \mathrm{~m}\right.$ water depth, temperatures from $-1.6^{\circ}$ to $1^{\circ} \mathrm{C}$ ) and is expressed in the equation

$$
\text { BWT }\left({ }^{\circ} \mathrm{C}\right)=\left(0.438 \times \mathrm{Mg} / \mathrm{Ca}_{\mathrm{Kg}}\right)-5.14 \quad\left(r^{2}=0.5\right) \quad(\text { ref. } 14)
$$


This calibration has a $1 \sigma$ prediction error of $\pm 1.0^{\circ} \mathrm{C}$ (Supplementary Fig. S1; ref. 14) and a temperature sensitivity of $\sim 2.3 \mathrm{mmol} \mathrm{mol}^{-1}{ }^{\circ} \mathrm{C}^{-1}$. This sensitivity is nearly double that of Krithe species from the North Atlantic (temperature range of $2^{\circ}-14^{\circ} \mathrm{C}$; ref. 13) but similar to that from Coral Sea Krithe $\mathrm{Mg} / \mathrm{Ca}$ (temperatures $2^{\circ}-6^{\circ} \mathrm{C}$; see Supplementary Information).

Age models for central Arctic cores are based on 199 calibrated radiocarbon dates mostly on the planktonic foraminifers Neogloboquadrina pachyderma discussed in Supplementary Information. The average two-standard-deviation error on calibrated ages older than $40 \mathrm{kyr}$ was $\pm 1,648$ years; for ages $39 \mathrm{kyr}$ to $20 \mathrm{kyr}, \pm 1,003$ years; and ages $20 \mathrm{kyr}$ to recent \pm 199 years.

Received 16 March 2012; accepted 23 July 2012; published online 26 August 2012

\section{References}

1. Stroeve, J., Holland, M. M., Meier, W., Scambos, T. \& Serreze, M. Arctic sea ice decline: Faster than forecast. Geophys. Res. Lett. 34, L09501 (2007).

2. Maslanik, J. A. et al. A younger, thinner Arctic ice cover: Increased potential for rapid, extensive sea-ice loss. Geophys. Res. Lett. 34, L24501 (2007).

3. Polyakov, I. V. et al. Fate of early 2000s Arctic warm water pulse. Bull. Amer Meteor. Soc. 92, 561-566 (2011).

4. Wang, M. \& Overland, J. E. A sea ice free summer Arctic within 30 years? Geophys. Res. Lett 36, L07502 (2009).

5. Arrigo, K. R., van Dijken, G. \& Pabi, S. Impact of a shrinking Arctic ice cover on marine primary production. Geophys. Res. Lett. 35, L19603 (2008).

6. Bates, N. R. \& Mathis, J. T. The Arctic Ocean marine carbon cycle: Evaluation of air-sea $\mathrm{CO}_{2}$ exchanges, ocean acidification impacts and potential feedbacks. Biogeosciences 6, 2433-2459 (2009).

7. Grebmeier, J. M. et al. A major ecosystem shift in the northern Bering Sea. Science 311, 1461-1464 (2006).

8. Kaufman, D. S. et al. Recent Warming Reverses Long-Term Arctic Cooling. Science 325, 1236-1239 (2009).

9. Moran, K. et al. The Cenozoic palaeoenvironment of the Arctic Ocean. Nature 441, 601-605 (2006).

10. Polyak, L. et al. History of sea ice in the Arctic. Quat. Sci. Rev. 29, $1757-1778$ (2010)

11. Karcher, M. J. \& Oberhuber, J. M. Pathways and modification of the upper and intermediate waters of the Arctic Ocean. J. Geophys. Res. 107, 3049 (2002).

12. Rudels, B., Jones, E. P., Schauer, U. \& Eriksson, P. Atlantic sources of the Arctic Ocean surface and halocline waters. Polar Res. 23, 181-208 (2004).

13. Dwyer, G. S. et al. North Atlantic deepwater temperature change during late Pliocene and late Quaternary climatic cycles. Science 270, 1347-1351 (1995).

14. Farmer, J., Cronin, T. M. \& Dwyer, G. S. Ostracode Mg/Ca Paleothermometry in the North Atlantic and Arctic Oceans: Evaluation of a carbonate ion effect. Paleoceanography 27, PA2212 (2012).

15. Dwyer, G. S., Cronin, T. M. \& Baker, P. A. in The Ostracode: Applications in Quaternary Research Vol. 131 (eds Holmes, J. A. \& Chivas, A. R.) 205-225 (Geophysical Monograph, American Geophysical Union, 2002).

16. Polyak, L., Darby, D. A., Bischof, J. F. \& Jakobsson, M. Stratigraphic constraint on late Pleistocene glacial erosion and deglaciation of the Chukchi margin, Arctic Ocean. Quat. Res. 67, 234-245 (2007).

17. Rohling, E. J. \& Pälike, H. Centennial-scale climate cooling with a sudden cold event around 8,200 years ago. Nature 434, 975-979 (2005).

18. Bauch, H. A. et al. A multiproxy reconstruction of the evolution of deep and surface waters in the subarctic Nordic seas over the last 30,000 yr. Quat. Sci. Rev. 20, 659-678 (2001).
19. Rasmussen, T. L. \& Thomsen, E. Ventilation changes in intermediate water on millennial time scales in the SE Nordic seas, 65-14 kyr BP. Geophys. Res. Lett. 36, L01601 (2009).

20. Hald, M., Dokken, T. \& Mikalsen, G. Abrupt climatic change during the last interglacial-glacial cycle in the polar North Atlantic. Mar. Geol. 176, 121-137 (2001)

21. Marcott, S. A. et al. Ice-shelf collapse from subsurface warming as a trigger for Heinrich events. Proc. Natl Acad. Sci. USA 108, 13415-13419 (2011).

22. Dokken, T. M. \& Jansen, E. Rapid changes in the mechanism of ocean convection during the last glacial period. Nature 401, 458-461 (1999).

23. Meland, M. Y., Dokken, T. M., Jansen, E. \& Hevrøy, K. Water mass properties and exchange between the Nordic seas and the northern North Atlantic during the period 23-6 ka: Benthic oxygen isotopic evidence. Paleoceanography 23, PA1210 (2008)

24. Stanford, J. D. et al. A new concept for the paleoceanographic evolution of Heinrich event 1 in the North Atlantic. Quat. Sci. Rev. 30, 1047-1066 (2011).

25. Cronin, T. M. et al. Quaternary Sea-ice history in the Arctic Ocean based on a new Ostracode sea-ice proxy. Quat. Sci. Rev. 29, 3415-3429 (2010).

26. Jakobsson, M. et al. An Arctic Ocean ice shelf during MIS 6 constrained by new geophysical and geological data. Quat. Sci. Rev. 29, 3505-3517 (2010).

27. Haley, B. A., Frank, M., Spielhagen, R. F. \& Eisenhauer, A. Influence of brine formation on Arctic Ocean circulation over the past 15 million years. Nature Geosci. 1, 68-72 (2008).

28. Nilsson, J. \& Walin, G. Salinity-dominated thermohaline circulation in sill basins: Can two stable equilibria exist? Tellus 62A, 123-133 (2010).

29. Darby, D. A., Polyak, L. \& Jakobsson, M. The 2005 HOTRAX Expedition to the Arctic Ocean. Glob. Planet. Change 68, 1-4 (2009).

30. Svensson, A. et al. A 60000 year Greenland stratigraphic ice core chronology. Clim. Past 4, 47-57 (2008).

\section{Acknowledgements}

We thank E. Brouwers, C. Callicott, L. Gemery, T. Ichinose, R. Kihl, T. Nettleton, and N. Seevers for sample processing, E. Klein for use of the atomic emission spectrometer, R. Poirier for chronology, T. Rasmussen, D. Darby, P. De Deckker and R. Marzen for graphics, and C. Merz, C. Vogt and R. DeConto for helpful discussions. T.M.C., J.F. and G.S.D. are financially supported by the US Geological Survey Global Change Program; W.M.B. by National Science Foundation Grant OPP-9400,255; H.A.B. and R.F.S. received financial support from the Academy of Sciences, Humanities, and Literature Mainz through the 'Akademienprogramm'. The Swedish contribution was supported by a grant from the Knut and Alice Wallenberg Foundation.

\section{Author contributions}

T.M.C. coordinated the study, analysed the data and wrote most of the paper, G.S.D. and J.F. conducted the $\mathrm{Mg} / \mathrm{Ca}$ and $\mathrm{Sr} / \mathrm{Ca}$ analyses, R.F.S. contributed chronology and interpretation of MIS3-1 results, M.J. contributed material, age model for HLY0503-18TC and oceanographic interpretation, J.N. developed the oceanographic model, Krithe identified by W.M.B., from P1-AR-94 cores, A.S. and H.A.B. provided Krithe and chronology from PS51-154, H.A.B. contributed Krithe, proxy records and chronology from PS1243, and oceanographic interpretation.

\section{Additional information}

Supplementary information is available in the online version of the paper. Reprints and permissions information is available online at www.nature.com/reprints. Correspondence and requests for materials should be addressed to T.M.C.

\section{Competing financial interests}

The authors declare no competing financial interests. 